\title{
ДОСЛІДЖЕННЯ ТА МОНІТОРИНГ ІМУНОСУПРЕСИВНОГО СТАТУСУ В ПАЦІЄНТІВ ІЗ РЕВМАТОЇДНИМ АРТРИТОМ
}

Дослідження та моніторинг імуносупресивного статусу в пацієнтів із ревматоїдним артритом

О. І. Зарудна, А. А. Гонт, Д. О. Зарудна, С. В. Даньчак, Є. Є. Єлісєєв

Тернопільський національний медичний університет імені І. Я. Горбачевського МОЗ України

Резюме. У статmі наведено результати дослідження імуносупресивного статусу пацієнтів із ревматоїдним артритом (РА) з метою оцінки безпеки стандартних схем лікування даного захворювання.

Мета дослідження - оцінити вплив стандартного лікування РА на імунний статус пацієнтів та його безпеку, використовуючи доступні скринінгові методи діагностики та опитувальники.

Матеріали і методи. Проведено оцінку програм лікування 65 хворих із встановленим діагнозом РА. Використано скринінгові методи діагностики, а саме, визначення загального числа лейкоцитів та лімфоцитів крові. А також хворим було запропоновано опитувальники для оцінки частоти інфрекційних процесів.

Результати. Для детального вивчення явища керованої імуносупресії у хворих на РА, їх поділено за імуносупресивним статусом: 50 - відносяться до таких, які мають імуносупресивний статус, 8 - низький імуносупресивний статус та 7 із невизначеним статусом. Проведено визначення кількості лейкоцитів та лімфоцитів у даних групах. З'ясовано, що жоден результат не виходить за межі загальновідомих норм. Виявлено, що число лейкоцитів навіть вище у пацієнтів із імуносупресивним статусом, проте кількість лімсроцитів - основних клітин імунного захисту - у них достовірно нижча порівняно з пацієнтами, які на час проведення дослідження не отримували імуносупресивних агентів. Якісний аналіз опитувальників, запропонованих в дослідженні, медичних карт стаціонарного хворого та виписних епікризів пацієнтів виявив, що хворі з імуносупресивним статусом вказували на застуди на $20 \%$ частіше, ніж хворі з низьким імуносупресивним статусом.

Висновки. Загальна оцінка числа лейкоцитів та лімфоцитів як методу скринінгу не виявила особливих відхилень від норми у хворих на РА, які отримують імуносупресивну терапію. Проте детальніший аналіз у групах відповідно до статусу з'ясував, що попри достатню кількість числа лейкоцитів у хворих з імуносупресивним статусом страждає їх якісний склад за рахунок достовірного зниження числа лімфоцитів. Якісний аналіз дослідної та медичної документації виявив вищу частоту інфекційних процесів в анамнезі у
Investigation and monitoring of immunosupressive status in patients with rheumatoid arthritis

O. I. Zarydna, A. A. Hont, D. O. Zarudna, S. V. Danchak, Y. Y. Yelisieiev

I. Horbachevsky Ternopil National Medical University

e-mail: zarudna@tdmu.edu.ua

Summary. The article presents the results of a study of the immunosuppressive status in patients with rheumatoid arthritis to assess the safety of standard treatment regimens for this disease.

The aim of the study - to assess the impact of standard RA treatment of patients' immune status and safety using diagnostic screening methods and questionnaires.

Materials and Methods. The treatment programs of 65 patients diagnosed with RA were evaluated. Screening diagnostic methods were used: determination of the total number of leukocytes and blood lymphocytes. Patients were also offered questionnaires to assess the frequency of infectious processes.

Results. To study the phenomenon of controlled immunosuppression in RA patients, they were divided according to their immunosuppressive status: 50 - those with immunosuppressive status, 8 - with low immunosuppressive status and 7 with indeterminate status. The number of leukocytes and lymphocytes in these groups was determined. It was determined that no result goes beyond the normal ranges. It was found that the number of leukocytes was even higher in patients with immunosuppressive status, butlymphocytes were significantlylowercompared to patients who did not receive immunosuppressive agents during the study. Qualitative analysis of questionters and medical records revealed that patients with immunosuppressive status showed an infections $20 \%$ more often than patients with low immunosuppressive status.

Conclusions. The assessment of white blood cell and lymphocyte counts, as a screening method, did not reveal significant abnormalities in RA with immunosuppressive therapy. However, a more detailed analysis of the group according to the status revealed that besides sufficient number of leukocytes in patients with immunosuppressive state, they have a significant decrease in the number of lymphocytes. Qualitative study of the questioneers and medical records revealed a higher ratio of infectious process in patients with RA and immunosuppressive status than in cases with low immunosuppressive status. 
пацієнтів із РА та імуносупресивним статусом, ніж у пацієнтів з низьким імуносупресивним статусом.

Ключові слова: ревматоїдний артрит; імуносупресивний статус; опитувальник.

\section{ВСТУП}

Ревматоїдний артрит (РА) - це автоімунна хвороба з невідомою етіологією, для якої характерним $€$ ерозивний артрит (синовіїт) та широкий спектр позасуглобових (системних) проявів.

Етіологічні фрактори до сьогодні невідомі. Встановлено лише, що хвороба реалізується за умови впливу несприятливих фракторів (куріння, вірусна інфекція, стресові фрактори тощо) на тлі генетичної схильності до її розвитку (носійство HLA-DRB1*0401, HLA-DRB1*0404). Відсутність етіологічного чинника, відомої причини виникнення хвороби й ускладнює лікування, оскільки змушує перш за все впливати на механізми автоімунного патогенезу хвороби [2, 6, 7]. Враховуючи хронічний характер перебігу недуги та циклічність її розвитку з чергуванням періодів загострення та стабілізації, логічно, що тактика лікування сьогодні базується на принципах керованої або контрольованої імуносупресії. Термін «керована імуносупресія» в науковій літературі частіше зустрічається щодо тактики ведення пацієнтів із трансплантованими органами, які отримують препарати імуносупресивного ряду $[4,5,8]$. Проте ситуація з автоімунними захворюваннями, зокрема РА, зовсім не відрізняється від такої при трансплантації органів, оскільки вимагає тримати під контролем фрункцію імунної системи. Отже, керована імуносупресія - це пригнічення імунної системи для контролю за автоімунним захворюванням при максимальній збереженості протиіноекційного імунітету. Основою успішної імуносупресивної терапії у цьому випадку є принцип «балансу», тобто фахівець повинен призначити дозування препаратів, необхідне для адекватного контролю РА, і разом з тим не збільшити загальний ризик для життя і здоров'я пацієнта. Несистематичний контроль за адекватністю імуносупресивної терапії може призвести до недостатньої її ефрективності, або до токсичного впливу високих доз імуносупресорів на органи і системи, в тому числі й на систему імунітету, що сприяє розвитку тяжких іноекцій та їх ускладнень (В.И.Шумаков, 1982). Ці твердження набули особливого значення протягом останніх 2-х років із початком пандемії COVID-19. Науковці усього світу все ще намагаються прогнозувати та, за можливості, попереджувати тяжкий перебіг ковідної хвороби у пацієнтів, які постійно отримують імуносупресивну терапію для контролю над своїм захворюванням [1, 3, 9].

За тяжкістю ураження суглобів ревматоїдний артрит не має собі рівних серед інших захворювань опорно-рухової системи. Ураження суглобів супроводжується орормуванням контрактур і розвитком
Key words: rheumatoid arthritis; immunosuppressive status; questionnaire.

десормацій кінцівок, які призводять до часткової або повної втрати працездатності. Тому для лікування цього патологічного стану використовується тактика «treat-totarget» (лікування до мети) із застосуванням препаратів імуносупресивного ряду, що вимагає підвищеної уваги до їх імунного статусу з метою мінімізації інорекційних ризиків, особливо в час пандемії COVID-19.

Метою дослідження було оцінити вплив стандартного лікування РА на імунний статус пацієнтів та його безпеку, використовуючи доступні скринінгові методи діагностики та опитувальники.

\section{МАТЕРІАЛИ ТА МЕТОДИ}

Для реалізації мети проведено обстеження та аналіз програм лікування 65 хворих із встановленим діагнозом РА, які перебували на стаціонарному лікуванні в ревматологічному відділенні Тернопільської університетської лікарні за період 2014-2020 рр.

3 метою оцінки впливу стандартного лікування РА на імунний статус пацієнтів використано скринінгові методи діагностики, а саме, визначення загального числа лейкоцитів та лімфроцитів крові за загальноприйнятою методикою виконання загального аналізу крові з відносним підрахунком показників лейкоцитарної формули. А також хворим було запропоновано опитувальники для оцінки частоти інфрекційних процесів.

\section{РЕЗУЛЬТАТИ Й ОБГОВОРЕННЯ}

80 \% з усіх пацієнтів у даному дослідженні жінки. Середній вік обстежених $(52,8 \pm 1,3)$ року. В абсолютної більшості пацієнтів (92 \%) хвороба має активний перебіг (за DAS 28), а низьку активність виявлено лише у 8 \% хворих.

Перед аналізом кількості лейкоцитів та лімфоцитів пацієнтів необхідно навести перелік відомих імуносупресивних агентів, які використовуються для лікування автоімунних захворювань, зокрема РА (табл. 1).

Більшість пацієнтів із РА отримує ліки для контролю за своєю хворобою саме з цього переліку, оскільки вони входять до рекомендацій EULAR та ACR щодо лікування даної недуги. Метою лікування PA $€$ клінічна ремісія за визначенням ACR/EULAR або принаймні низька активність Хвороби, якщо досягнення ремісії є малоймовірним, шляхом підбору імуносупресивного базисного препарату.

Для більш детального вивчення явища керованої імуносупресії у хворих на РА їх було поділено за їх імуносупресивним статусом (табл. 2). 
Таблиця 1. Перелік імуносупресивних агентів

$>$ ГКС

- Синтетичні ХМАРПи: «Метотрексат», «Лефрлуномід», «Сульфрасалазин», «Плаквеніл», «Азатіоприн»

- Мофретилу мікофренолат

- Інгібітори кальциневрину: «Циклоспорин», «Такролімус»

- Алкілуючі агенти: «Циклофроссромід»

- Біологічні ХМАРПи: «Інфрліксимаб», «Етанерцепт», «Адалімумаб», «Цертолізумаб», «Голімумаб», «Абатацепт»,

«Тоцилізумаб», «Ритуксимаб», «Секукінумаб», «Ікзекізумаб», «Белімумаб», «Анакінра», «Санакінумаб»

- Таргетні синтетичні ХМАРПи: «Тофрацитиніб», «Барицитиніб»

Джерело: https://ard.bmj.com/content/annrheumdis/79/1/39.full.pdf

Таблиця 2. Визначення імуносупресивно статусу

Імуносупресивний статус це:

- ГКС: $\geq 2$ тижнів $\geq 20$ мг/добу або 2 мг/кг/добу (усе в перерахунку на «Преднізолон»)

- «Метотрексат» $\geq 0,4$ мг/кг/добу

- «Азатіоприн» $\geq 3,0$ мг/кг/добу

- Біологічні ХМАРПи

- Таргетні ХМАРПи

Низький імуносупресивний статус це:

- Використання нижчих доз вказаних препаратів

- Тривале використання ГКС у малих дозах

Джерело: Furer V. et al. Ann Rheum Dis 2020;79:39-52.

Отже, серед когорти обстежених пацієнтів - 50 відносяться до таких, які мають імуносупресивний статус, 8 - низький імуносупресивний статус та 7 із невизначеним статусом, оскільки на час обстеження не отримували імуносупресивних агентів у зв'язку 3 наявністю протипоказань, зміною препарату чи іншими обставинами.

Для детальнішого аналізу проведено визначення кількості лейкоцитів та лімфоцитів у даних групах (табл. 3).

При аналізі таблиці 3 виявлено, що жоден результат не виходить за межі загальновідомих норм. Виявлено, що число лейкоцитів навіть вище у пацієнтів із імуносупресивним статусом, проте кількість лімфоцитів - основних клітин імунного захисту - В них достовірно нижча порівняно з пацієнтами, які на час проведення дослідження не отримували імуносупресивних агентів.

Крім цього, якісний аналіз опитувальників, запропонованих у дослідженні, медичних карт стаці- онарного хворого та виписних епікризів пацієнтів виявив, що хворі з імуносупресивним статусом вказували на застуди на 20 \% частіше, ніж хворі 3 низьким імуносупресивним статусом. У групу хворих 3 імуносупресивним статусом потрапили також 2 пацієнти з тяжким перебігом пневмонії в анамнезі, 1 хворий - з остеомієлітом в анамнезі. Отже, власне керована імуносупресія (ретельне медичне спостереження та навчання пацієнта) є вкрай необхідною у таких обставинах.

У хворих із низьким імуносупресивним статусом не виявлено тяжких чи частих інфеекційних процесів в анамнезі, 1 пацієнт згадував про локальні інфекції шкірних покривів. Проте навіть таку інсрормацію ігнорувати неможливо та необхідно проводити імуносупресивну терапію в режимі ретельного контролю.

У пацієнтів із невизначеним статусом (на час дослідження не отримували імуносупресивної терапії із різних причин) загальне число лейкоцитів виявилось достовірно нижче від такого у пацієнтів,

Таблиця 3. Визначення кількості лейкоцитів та лімфоцитів у групах хворих за імуносупресивним статусом

\begin{tabular}{l|c|c}
\hline \multicolumn{1}{c|}{ Група хворих } & Лейкоцити, Г/л & Лімсоцити, \% \\
\hline $\begin{array}{l}\text { Перша група - імуносупресивний статус } \\
(\mathrm{n}=50)\end{array}$ & $8,85 \pm 0,43$ & $23,00 \pm 2,11$ \\
& $\mathrm{p}_{1}<0,05$ & $\mathrm{p}_{2}>0,05$ \\
& $\mathrm{p}_{2}>0,05$ & \\
\hline $\begin{array}{l}\text { Друга група - } \\
\text { низький імуносупресивний статус }(\mathrm{n}=8)\end{array}$ & $7,28 \pm 0,35$ & $24,67 \pm 2,15$ \\
\hline $\begin{array}{l}\text { Третя група - } \\
\text { невизначений статус }(\mathrm{n}=7)\end{array}$ & $6,40 \pm 0,21$ & $28,48 \pm 3,02$ \\
\hline
\end{tabular}

Примітки: 1) $p_{1}$ - різниця між першою та другою групами;

2) $p_{2}$ - різниця між першою та третьою групами. 
які отримують імуносупресивні агенти, проте якісний склад їх кращий за рахунок достовірно вищого числа лімсооцитів.

\section{ВИСНОВКИ}

Загальна оцінка числа лейкоцитів та лімфроцитів, як методу скринінгу, не виявила особливих відхилень від норми у хворих на РА, які отримують імуносупресивну терапію. Проте детальніший аналіз у групах відповідно до статусу з'ясував, що попри достатню кількість числа лейкоцитів у хворих 3 імуносупресивним статусом страждає їх якісний склад за рахунок достовірного зниження числа лімфоцитів. Це може свідчити про підвищену схильність пацієнтів до інфекційних процесів. Дана інфрормація набуває особливої актуальності у часи

\section{СПИСОК ЛІТЕРАТУРИ}

1. Національна академія медичних наук України. Iнформаційні матеріали. Актуальні рекомендації для ревматологів у зв'язку із пандемією COVID-19: ревматичні захворювання та коронавірусна інфрекція COVID-19 [опубліковано 10.04.2020]. Доступно на: http://amnu.gov. ua/aktualni-rekomendacziyi-dlya-revmatologiv-u-zv-yazkuiz-pandemiyeyu-covid-19-revmatychni-zahvoryuvannya-takoronavirusna-infekcziya-covid-19.

2. Гонт А. А. Ревматоїдний артрит - історія, сучасні погляди, тактика, результат / А. А. Гонт, О. І. Зарудна. M., 2021. - № 4. - С. 30-6. Доступно на: https://ojs.tdmu. edu.ua/index.php/nursing/article/view/11870.

3. Зарудна О. І., Зарудна Д. О. Особливості ведення ревматологічних хворих за умов пандемії COVID-19: співпраця первинної ланки та ревматолога / О. І. Зарудна, Д. О. Зарудна. - М., 2021. - № 3. - С. 9-13. Доступно на: https://ojs.tdmu.edu.ua/index.php/nursing/article/ view/11676

4. Імуносупресивна терапія після трансплантації нирки : Рекомендації Європейської асоціації урологів, 2004) // Ліки України. - 2008. № 5(121). - С. 72-76. Доступно на: https://www.health-medix.com/articles/liki_ukr/2008-0622/72-76.pdf.

5. Сускова В. С. Принципы оптимизации иммуносупрессиии при аллотрансплантации органов : дисс на

\section{REFERENCES}

1. National Academy of Medical Sciences of Ukraine. Information materials. Current guidelines for rheumatologists in connection with the COVID-19 pandemic: rheumatic diseases and coronavirus infection COVID-19. Available from: http://amnu.gov.ua/aktualni-rekomendacziyi-dlyarevmatologiv-u-zv-yazku-iz-pandemiyeyu-covid-19revmatychni-zahvoryuvannya-ta-koronavirusna-infekcziyacovid-19/. Ukrainian.

2. Hont AA, Zarudna OI. Rheumatoid arthritis - history, modern views, tactics, results. [Ревматоїдний артрит історія, сучасні погляди, тактика, результат] Moscow; 2021. Available from: https://ojs.tdmu.edu.ua/index.php/ nursing/article/view/11870. Ukrainian. пандемії COVID-19, оскільки імуноскомпроментовані пацієнти можуть мати тяжчий та ускладнений перебіг ковідної хвороби.

Одночасно якісний аналіз дослідної та медичної документації виявив вищу частоту інфекційних процесів в анамнезі у пацієнтів із РА та імуносупресивним статусом, ніж у пацієнтів з низьким імуносупресивним статусом.

Узагальнюючи вищевикладене, необхідно констатувати, що для досягнення мети у хворих на РА повинна застосовуватись імуносупресивна терапія, оскільки альтернативи на даний час немає. Одночасно необхідно проводити ретельний медичний моніторинг пацієнта, який отримує базисну терапію з метою уникнення та попередження тяжких інорекційних ускладнень вказаного лікування.

соискание уч. степени / В. С. Сускова. - М. : Молми им. И. М. Сеченова, 1989. - 126 с.

6. Унісрікований клінічний протокол первинної, вторинної (спеціалізованої), третинної (високоспеціалізованої) медичної допомоги та медичної реабілітації «Ревматоїдний артрит»: наказ Міністерства охорони здоров'я України від 11.04.2014 р. № 263.

7. Хіміон Л. В. Тактика ведення хворих на ревматоїдний артрит лікарем загальної практики - сімейним лікарем / Л. В. Хіміон, О. Б. Ященко, С. В. Данилюк // Семейная медицина. - 2016. - № 2 (64). - С. 6-15.

8. Cyclosporine withdrawal from a mycophenolate mofetil-containing immunosuppressive regimen in stable kidney transplant recipients: a randomized, controlled study / D. Abramowicz, D. Manas, M. Lao [et al.] // Transplantation. - 2002. - Vol. 74 (12). - P. 1725-1734. DOI: $\quad 10.1097 / 00007890-200212270-00015 . \quad$ PMID: 12499889

9. NICE. NICE Guidance. VID-19 rapid guidline: rheumatological autoimmune inflammatory and metabolic bone disorders. NICE guideline [NG167]. 2020 [updated 31 March 2021]. Available from: https://www.nice.org.uk/ guidance/ng167/chapter/3-Patients-known-or-suspectedto-have-COVID-19.

3. Zarudna OI, Zarudna DO. Features of rheumatological patients in the pandemic COVID-19: cooperation of primary care and rheumatologist. [Особливості ведення ревматологічних хворих за умов пандемії COVID-19: співпраця первинної ланки та ревматолога] Moscow; 2021. Available from: https://ojs.tdmu.edu.ua/index.php/nursing/ article/view/11676. Ukrainian.

4. [Immunosuppressive therapy after kidney transplantation: Recommendations of the European Association of Urologists, 2004]. Liky Ukr. 2008;5(121): 726. Available from: https://www.health-medix.com/articles/ liki_ukr/2008-06-22/72-76.pdf. Ukrainian.

5. Suskova VS. Principles of optimization of 
immunosuppression in organ allotransplantation. Thesis. Moscow: MOLMI im IM Sechenov; 1989. Russian.

6. Unified clinical protocol of primary, secondary (specialized), tertiary (highly specialized) medical care and medical rehabilitation "Rheumatoid arthritis": order of the Ministry of Health of Ukraine of April 4, 2014, No. 263. Ukrainian.

7. Himion LV, Yashchenko OB, Danilyuk SV. [Tactics of management of patients with rheumatoid arthritis by a general practitioner - a family doctor]. Simein med. 2016;2(64): 6-15. Ukrainian.
8. Abramowicz D, Manas D, Lao M. Cyclosporine withdrawal from a mycophenolate mofetil-containing immunosuppressive regimen in stable kidney transplant recipients: a randomized, controlled study. Transplantation. 2002;74(12): 1725-34. DOI: 10.1097/00007890-20021227000015. PMID: 12499889.

9. NICE. NICE Guidance. VID-19 rapid guidline: rheumatological autoimmune inflammatory and metabolic bone disorders. NICE guideline [NG167]. 2020 [updated 31 March 2021]. Available from: https://www.nice.org.uk/ guidance/ng167/chapter/3-Patients-known-or-suspectedto-have-COVID-19. 